the rectum instead of into anal vesicles; (4) the ovary is restricted to the extreme posterior end, and is iransversely situated; (5) presence of a well-defined siphon associated with the anterior part of the intestine, with which it communicates by means of a greatly folded region; (6) the presence of a distinct invagination of the body-wall between uterine openings (in this invagination, which the authors call the male tube or andrœcium, a tiny degenerate male is lodged); ( 7 ) though the female possesses from two to four ventral hooks, the male is devoid of them; (8) the presence of two vesiculæ seminales; and (9) the partial fusion of the male with the female, its posterior end being more or less enveloped by the tissues of the andrœcium, so that there is a very pronounced parasitism. The differences between the species under review and those belonging to other genera of Echiuroidea have led the authors to propose a new genus, Pseudobonellia ( $P$. biuterina, n.sp.), for this remarkable worm. Various stages in parasitism in sex relationship are referred to in the paper. -Dr. R. J. Tillyard : Mesozoic insects of Queensland. Part v. Mecoptera, the new order Paratrichoptera, and additions to the Planipennia. This part deals with six specimens, of which four are named. A new family, genus, and species of Mecoptera are described from the Upper Trias of Ipswich, having a sixbranched media, but with the first cubitus cut off short in a peculiar manner. Two very fine wings from the same horizon belong to Trichopterous-like insects, but have certain important differences in the venation, viz. the anal veins primitive and separate and the first cubitus without any apical fork. Together with the two allied genera already described, these are removed to a new order Paratrichoptera. In the Planipennia the same horizon yields a portion of a fine wing closely resembling that of the recent Megapsychops illidgei; this is placed in a new genus within the family. Prohemerobiidæ. The recent Psychopsidæ are shown to be the direct descendants of these. Some interesting evidence is forthcoming as to the nature of the vein called by Comstock the "posterior arculus," which is shown almost certainly to be a true posterior dichotomic branch of $\mathrm{M}$, and should, therefore, merit the notation $\mathrm{M}_{5}$.

Royal Society of New South Wales, July 2.-Prof. C. E. Fawsitt, president, in the chair.-Miss Marguerite Henry : Some Australian fresh-water Copepoda and Ostracoda. The present paper arose out of an investigation of the transmission of worm-nodules in cattle. In this investigation it was necessary to examine all the Crustacea that might have acted as intermediate hosts. Besides material collected at Kendall, where the work was principally carried on, some was collected at Lett River, Blue Mountains, Waterfall, Botany, Dorrigo, Byron Bay, Casino, Bangalow, Orange, Cumbalum, and Corowa Amongst the sixteen species collected, four were found to be new.-Rev. W. W. Watts : Some notes on Neurosoria pteroides. Results of an investigation into the structure and systematic position of a very rare fern from tropical Queensland. It was first published by Robert Brown as an Acrostichum, but Mettenius had created for it the new genus Neurosoria. The paper reviewed the work of previous students, and submitted careful notes of an independent examina. tion of the material available in Australia.-J. H. Maiden : Notes on Eucalyptus; No. vii., with descriptions of new species. Four species are proposed as new, viz. the "Morrel" of the eastern goldfields of Western Australia, which has hitherto been looked unon as a large-growing form of the red mallee (Eucalyptus oleosa); a narrow-leaved mallee from NO. 2600, VOL. IO3]
Comet Vale, in the same State; a tree from Bathurst Island, Northern Territory; and a mallee-like species from the summit of the Barren Mountain, BellingerClarence district. Discovery of $E$. bakeri in Queensland, together with additional notes of a technical character in regard to other eucalypts occurring in some of the other States.

\section{BOOKS RECEIVED.}

The Occlusion of Gases by Metals: A General Discussion held by the Faraday Society, November, 1918. (Reprinted from the Transactions of the Faraday Society, vol. xiv., parts 2 and 3, I919.) Pp. 93. (London: The Faraday Society, n.d.) $8 s .6 d$.

Fevers in the Tropics. By Sir Leonard Rogers. Third edition. (Oxford Medical Publications.) Pp. xii +404. (London: Henry Frowde and Hodder and Stoughton, I919.) 30s. net.

Menders of the Maimed: The Anatomical and Physiological Principles Underlying the Treatment of Injuries to Muscles, Nerves, Bones, and Joints. By Prof. A. Keith. (Oxford Medical Publications.) Pp. xii +335 . (London: Henry Frowde and Hodder and Stoughton, I9I9.) r6s. net.

Fossil Plants: A Text-book for Students of Botany and Geology. By Prof. A. C. Seward. Vol. iv.: Ginkgoales, Coniferales, Gnetales. Pp. xvi+543. (Cambridge: At the University Press, I9I9.) rl. Is.. net.

\section{CONTENTS.}

PAGE

War Wounds. By Dr. J. le Fleming Burrow . . . 50 r The Face of the Earth. By Prof. W. J. Sollas, F.R.S.

Physiological Chemistry. By $\dot{H}^{\circ} \dot{H}$ 'D. $\cdot{ }_{504}$ Our Bookshelf . . . . . . . . 504 Letters to the Editor:-

Velocity of Electric Currents.-Prof. Reginald A. Fessenden.

The Magnetic Storm of August ir-riz, igrg. - Dr. $\dot{C}^{\circ}$ Chree, F.R.S. ; Dr. A. Crichton Mitchell.

The James Watt Centenary Commemoration at Birmingham .. . . . . . . . . . . 507 Andrew Carnegie .. . . . . . . . . . 507 Walter Gould Davis. By R. C. M. . . . . . 508 Prof. William Gilson Farlow. By F. O. B. . . . 509 Notes ................. 510

Our Astronomical Column :-

Kopff's Comet 1906 IV. = r919a . . . . . . . . 5 I4 A New Comet . . . . . . . . . 514 Distribution of Globular Clusters and Spiral Nebulæ . 5 I4 A Planet beyond Neptune . . . . . . . 514 Photophoresis. By Robert W. Lawson. . . . . . 5 I4 Standards of Mass The Folk-songs of the Teton Sioux. By Prof. G. H. Bryan, F.R.S.

Electrical Purification of Clays . . . . . . . . . . . . . . Evolution in Potato-Beetles . . . . . . . . . 517 University and Educational Intelligence. . . . 517 Societies and Academies . . . . . . . . . . . 5 I8 Books Received. . . . . . . . . . . . . . . 520

Editorial and Publishing Offices: MACMILLAN AND CO., LTD., ST. MARTIN'S STREET, LONDON, W.C.2.

Advertisements and business letters to be addressed to the Publishers.

Editorial Communications to the Editor.

Telegraphtc Address: Phusis, London.

Telephone Number: GERRARD 8830. 